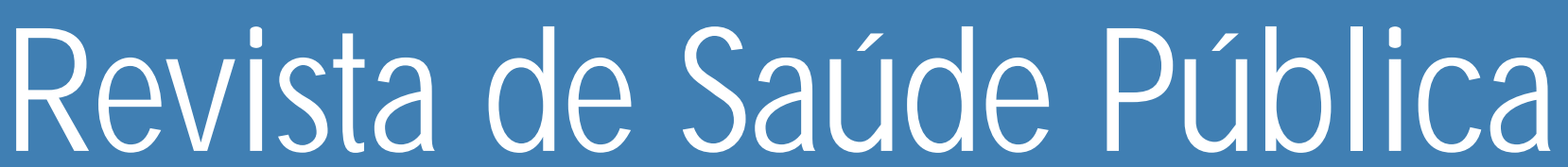

\begin{tabular}{lllllll}
\hline & 0 & $U$ & $R$ & $N$ & $A$ & $L$
\end{tabular}

$0 F$

P U

H $\quad E \quad A \quad L \quad T \quad H$

\title{
Survey of cyclopids ( Crustacea, Copepoda) in Brazil and preliminary screening of their potential as dengue vector predators
}

\section{Levantamento de ciclopídeos (Crustacea, Copepoda) no Brasil e avaliação preliminar de seu potencial como predadores dos vetores da dengue}

Luciana U rbano dos Santos e Carlos Fernando S. de Andrade Departamento de Parasitologia da Universidade Estadual de Campinas. Campinas, SP - Brasil (L.U.S.), Departamento de Zoologia da Universidade Estadual de Campinas. Campinas, SP Brasil (C.F.S.A.) 


\title{
Survey of cyclopids (Crustacea, Copepoda) in Brazil and preliminary screening of their potential as dengue vector predators*
}

\author{
Levantamento de ciclopídeos (Crustacea, Copepoda) no \\ Brasil e avaliação preliminar de seu potencial como predadores \\ dos vetores da dengue
}

\author{
Luciana Urbano dos Santos e Carlos Fernando S. de Andrade \\ Departamento de Parasitologia da Universidade Estadual de Campinas. Campinas, SP - Brasil \\ (L.U.S.), D epartamento de Zoologia da Universidade Estadual de Campinas. Campinas, SP - Brasil \\ (C.F.S.A.)
}

\begin{abstract}
Introduction

Cyclopid copepods are known to be good mosquito controllers, specially as regards the larvae of the dengue vectors Aedes aegypti and Ae. albopictus.

Material and Method

The objective of the study was to survey the local copepod fauna and search for new strains of M. longisetus var. longisetus, comparing the potential of the samples found with the current strain ML-01 against Ae. albopictus larvae, under laboratory conditions. Eleven bodies of water in Campinas, SP, Brazil, were screened for copepods by collecting $1.5 l$ of water from each of then. The predatory potential of adults copepods was evaluated over $24 \mathrm{~h}$, in the laboratory, for groups of 5 individuals preying upon 30 first instar Ae. albopictus larvae.

Results and Conclusion

The following cyclopid species were found: Metacyclops mendocinus, Tropocyclops prasinus, Eucyclops sp, Eucyclops serrulatus, Eucyclops solitarius, Eucyclops ensifer, Macrocyclops albidus var. albidus and Mesocyclops longisetus var. longisetus. The predatory potential of these copepods ranged from nil to $97.3 \%$. A sample collected in the field containing only $M$. longisetus var. longisetus showed the best control efficiency with no significant difference from a three-year old laboratory culture (ML-01) of the same species evaluated for comparison. The sample with few M. albidus var. albidus was ranked in second place showing an average $25.9 \%$ efficiency. The use of copepods in trap tires as dengue vector controllers is discussed.
\end{abstract}

Pest control biological. Aedes, fisiology. Crustacea, fisiology.

\section{Resumo}

Introdução

Copépodos ciclopídeos são conhecidos como bons controladores de mosquitos, especialmente quando considerado as larvas dos vetores da dengue Aedes aegypti $e$ Ae. albopictus.

\footnotetext{
*Apresentado no $15^{\circ}$ Congresso Brasileiro de Entomologia, Caxambu, MG, 1995.

Correspondência para/Correspondence to: Carlos Fernando S. Andrade - Caixa Postal 6109 - 13083-970 Campinas, SP - Brasil.

E-mail: cfeandra@obelix.unicamp.br.

Edição subvencionada pela FAPESP. Processo 96/5999-9.

Recebido em 4.9.1996. Reapresentado em 4.12.1996. Aprovado em 8.1.1997.
} 
Material e Método

Resultados e Conclusões
Onze corpos d'água em Campinas, SP, Brasil, foram avaliados para copépodos coletando-se 1,5 l de água de cada um deles. O potencial predador dos copépodos adultos foi avaliado por $24 \mathrm{~h}$, em laboratório, em grupos de 5 indivíduos predadando sobre 30 larvas de $1^{\circ}$ estádio de Ae. albopictus.

No presente levantamento as seguintes espécies de ciclopídeos foram encontradas: Metacyclops mendocinus, Tropocyclops prasinus, Eucyclops sp, Eucyclops serrulatus, Eucyclops solitarius, Eucyclops ensifer, Macrocyclops albidus var. albidus and Mesocyclops longisetus var. longisetus. O potencial predador desses copépodos variou de zero a 97,3\%. A amostra coletada no campo contendo apenas com M. longisetus var. longisetus mostrou a melhor eficiência de controle, sem diferença significativa de uma cultura de laboratório (ML-01) criada por 3 anos, desta mesma espécie, que foi avaliada para comparação. A amostra com poucos M. albidus var. albidus foi cotada em segundo melhor lugar, apresentando em média 25,9\% de eficiência. $O$ uso de copépodos em pneus armadilha como controladores dos vetores da dengue é discutido.

Controle biológico de vetores. Aedes, fisiologia. Crustáceos, fisiologia.

\section{INTRO D UCTIO N}

Two species of the genus Aedes have been continuously focused on in vector control campaigns in Brazil in relation to dengue and yellow fever epidemics. Aedes aegypti, considered in 1956 to have been eradicated, re-emerged and has been the main dengue vector in the country since the Boa Vista, RO epidemics in 1981/82 ${ }^{13}$. The second species, Aedes albopictus, was first recorded in Rio de Janeiro, RJ in $1986^{3}$. Supposedly introduced from Japan, this latter species has been considered a secondary dengue vector and a possible link between the presently eradicated urban yellow fever and the sylvatic form of the disease, due to its breeding habits in both urban and rural environments ${ }^{4,14}$. In 1994 the distribution pattern of both species in the State of S. Paulo encompassed 184 and 157 municipalities, respectively, for Ae. aegypti and Ae. albopictus, and a total of 209 distinct counties for the two species ${ }^{22}$.

The families Oithonidae and Cyclopinidae comprise predominantly salt water copepod species of the Order Cyclopoida, whereas the third family (Cyclopidae) is almost universally distributed along with mosquitoes in aquatic habitats such as wells, tree holes, lakes, reservoirs, fountains, salt marshes and even discarded tires ${ }^{12}$. Many forms of freshwater zooplankton have a broad diet but cyclopids show a particular interest in first instar mosquito larvae as prey.

Cyclopids are more effective for biological control than other predatory invertebrates because it is common for cyclopids to be numerically abundant even when mosquitoes are not present ${ }^{10}$. The potential of cyclopid crustaceans for the control of mosquitoes has been undergoing evaluation since the early 1980 ' $\mathrm{s}^{6,18,21}$. Field trials and even cyclopidbased programs for mosquito control have been carried out in many countries including Australia ${ }^{2}$, the United States ${ }^{11}$, Honduras ${ }^{10}$, Mexico ${ }^{15}$, Colombia $^{7}$ and Brazil ${ }^{23}$.

Four different Brazilian strains of Mesocyclops aspericornis from Fortaleza, CE in the Brazilian northeast have shown good potential as biological control agents of Ae. aegypti larvae, but were not as effective as an autochthonous Mesocyclops longisetus var. longisetus strain ${ }^{5}$. In a recent study, a strain of M. longisetus var. longisetus from Campinas, SP (ML-01) showed efficiencies higher than $97 \%$ for controlling Ae. albopictus larvae in trap tires in two field trials ${ }^{19}$. Projects on the use of copepods along with planarians and Bacillus thuringiensis var. israelensis are being carried out by the authors in education-based programs using trap tires. The introduction of copepods in natural mosquito breeding places in the county emerges too as a promising follow-up to this study. The aim of the present paper was to survey the local copepod fauna and search for new strains of $M$. longisetus var. longisetus, comparing the potential of the samples found with the current strain ML-01 against Ae. albopictus larvae, under laboratory conditions.

\section{MATERIAL AND METHOD}

\section{Survey}

Copepods were collected in Campinas, SP during June and July 1994. Eleven approximately equidistant areas were selected covering both urban and suburban locations of the county. In each area the water body possibly serving as a breeding place was screened by visual inspection, 
and samples of $1.5 \mathrm{l}$ of water were collected from a depth of from 5 to $15 \mathrm{~cm}$. The number of adult and immature copepods was then assessed in batches under laboratory conditions, the crustaceans remaining in the water in the field, without additional food for 15 to 20 days before the predation trials.

The areas sampled were: Area 1- The Municipal park "Parque do Taquaral" (TAQUA) located in an urban area. Collections were made alongside a 17 ha lake, in well insolated places. Area 2- The Municipal park "Parque Ecológico Monsenhor Emílio José Salim” (PEMJS), on the eastern outskirts of the city. Collections were made alongside a 10 ha lake, in well insolated places. Area 3- Forestry resource reserve "Mata de Santa Genebra" (MSGEN) consisting of 240 ha of semi-deciduous and mesophytic forest on the northwestern limits of the city. Collections were made from pools along a shady stream $0.7 \mathrm{~m}$ wide and $20 \mathrm{~cm}$ deep, on average. Area 4- District of Barão Geraldo (BARAO), on the northern outskirts of Campinas. Collections were made in a $0.5 \mathrm{~m}^{2}$ pool in a small shady swamp. This particular sampling site is on waste land close to secondary woodland. Area 5- Campus II of the Pontifícia Universidade Católica de Campinas- PUCCAMP (PUCII), located on the western boundary of the city. Collections were made in a pool of nearly $12 \mathrm{~m}^{2}$ formed by a permanent stream. Area 6- Central Campus of the PUCCAMP, located in downtown Campinas (PUCCC). Collections were made in the tiled pool of an artificial fountain covering $10 \mathrm{~m}^{2}$ in area and $0.45 \mathrm{~m}$ deep. This fountain is located in the old yard of the school buildings. Areas 7 and 8- Largo do Pará (LPARA) and Centro de Convivência (CCONV) are downtown squares. Collections were made in tiled pools of nearly $200 \mathrm{~m}^{2}$ in area and $0.25 \mathrm{~m}$ in depth. Area 9- Square of the Castro Mendes theater in a western suburb of the city (TCMEN). Collections were made also in the tiled pool of an artificial fountain of $28 \mathrm{~m}^{2}$ in area and $0.20 \mathrm{~m}$ in depth. Area 10- UNICAMP campus (UNICA). Two collections were made, one in a $1 \mathrm{~m}^{3}$ rain water reservoir (paras) and the other in the central fountain nearly $1900 \mathrm{~m}^{2}$ in area and $0.50 \mathrm{~m}$ in depth (cbasi). Area 11- A small roadside stream on the northeastern limits of the city (DPEDR). Collections were made in natural pools close to the banks of the stream.

Those water samples which were positive for copepods were analyzed for temperature, $\mathrm{pH}$, dissolved $\mathrm{O}_{2}$, nitrite, nitrate and ammonia.

\section{Predatory Potential}

Adult copepods from each positive sample were evaluated for predatory potential in groups of 5 individuals preying upon 30 first instar Ae. albopictus larvae. M. longisetus var. longisetus from a laboratory culture (ML-01) maintained for the last 3 years were also evaluated for comparison. The size of females with egg sacs was used as indicative of adult forms. Some individuals (from each sample) were saved in order to serve as eventual founders of new cultures. Four replicate cultures along with two controls (only copepods and only mosquitoes) were established in the laboratory for each population sampled.
Mosquito larvae were offered to the copepods $24 \mathrm{~h}$ after their transfer to plastic vials containing $450 \mathrm{ml}$ of commercial spring water, with no additional food. Evaluations were made by counting mosquito larvae surviving $24 \mathrm{~h}$ thereafter ${ }^{10}$. The temperature was $24-25^{\circ} \mathrm{C}$. Data were corrected by using Abbott's formula ${ }^{1}$ and compared by Student's t-test.

After the evaluations all copepods were preserved in glycerinated alcohol (20\%) and sent to the Museum of Zoology of the State University of S. Paulo, USP (entry numbers from 12.270 to 12.280 ).

\section{RESULTS}

\section{Survey}

The water from two urban areas (CCONV and TCMEN) showed no copepods during in situ inspection, confirmed by laboratory examination. Additionally, in three areas the number of copepods obtained led to inconclusive identification, being represented by few individuals or only copepodids. The remaining areas showed 1 to 3 copepod species in each sample (Table 1).

The copepod identification was carried out after the predatory potential test, meaning that in 2 of the samples different species were evaluated together. In PEMJS the proportion was 4 Tropocyclops prasinus to 1 (M. longisetus var. longisetus) and in the sample RPEDR, Eucyclops sp, Eucyclops solitarius and Macrocyclops a. albidus rated as 3.5/ $1 / 0.5$, respectively.

\section{Predatory Potential}

Attempts to breed unidentified copepods in order to evaluate their predatory potential were unsuccessful. Due to the difficulty in unequivocally differentiating adults, late instar copepodids were used and represented $30 \%$ and $15 \%$ of two of the evaluated samples, respectively TAQUA and PEMJS.

The mortality percentage in the copepod control group was nil while for the $1^{\text {st }}$ instar Ae. albopictus larvae control group, mortality ranged from nil to $13.3 \%$.

The M. longisetus var. longisetus strain ML01 confirmed its high potential, preying on up to $92 \%$ Ae. albopictus larvae in a $24 \mathrm{~h}$ period. The samples collected showed a variation ranging from nil to $97.3 \%$ (24h), this later performance (UNICA/ paras) being the only one with no significant difference from that showed by the ML-01 strain (Table 2). 
Table 1- Sampled area/place, location characteristics, copepod species and density (n/1.5 I) found in Campinas, SP, Brazil.

\begin{tabular}{|c|c|c|c|}
\hline Area /place & Location & Copepod species & Density $\mathrm{n} / 1.5 \mathrm{I}$ \\
\hline $1-\mathrm{TAQUA}$ & suburban & Eucyclops serrulatus & 40 \\
\hline \multirow[t]{2}{*}{2 - PEMJS } & suburban & Tropocyclops prasinus & 32 \\
\hline & & Mesocyclops longisetus var. longisetus & \\
\hline 3 - MSGEN & suburban & unidentified & 3 \\
\hline 4 - BARAO & suburban & Eucyclops ensifer & 35 \\
\hline $5-\mathrm{PUCC} I$ & suburban & unidentified & 4 \\
\hline $6-\mathrm{PUCCC}$ & central urban & unidetified & 5 \\
\hline 7 - LPARA & central urban & Eucyclops serrulatus & 70 \\
\hline $8-\mathrm{CCONV}$ & central urban & - & 0 \\
\hline 9 - TCMEN & suburban & - & 0 \\
\hline $10-$ UNICA & suburban & & \\
\hline /cbasi & & M etacyclops mendocinus & 32 \\
\hline /paras & & M esocyclops longisetus var. longisetus & 80 \\
\hline \multirow[t]{3}{*}{11 - DPEDR } & suburban & Eucyclops sp & 42 \\
\hline & & M acrocyclops albidus var. albidus & \\
\hline & & Eucyclops solitarius & \\
\hline
\end{tabular}

* See in material and method the complete area names.

Table 2 - M ean efficiency of copepods from different areas of Campinas, SP, Brazil as predators of Ae. albopictus larvae under laboratory conditions. The M L-01 strain of M. longisetus var. Iongisetus was used for comparison.

\begin{tabular}{lccc}
\hline Areas/places & Efficiency (\%) & $\mathrm{p}=0.05$ & $\mathrm{p}=0.01$ \\
\hline UNICA/paras & 97.30 & $\mathrm{a}^{*}$ & $\mathrm{~A}$ \\
MI - 01 & 92.47 & $\mathrm{a}$ & $\mathrm{A}$ \\
PEM JS & 25.90 & $\mathrm{~b}$ & $\mathrm{~B}$ \\
DPEDR & 13.38 & $\mathrm{~b} \mathrm{c}$ & $\mathrm{B}$ \\
LPARA & 3.42 & $\mathrm{C}$ & $\mathrm{B}$ \\
UNICA/cbasi & 2.77 & $\mathrm{C}$ & $\mathrm{B}$ \\
BARAO & 1.65 & $\mathrm{C}$ & $\mathrm{B}$ \\
TAQUA & 0.00 & $\mathrm{C}$ & $\mathrm{B}$ \\
\hline
\end{tabular}

Values followed by the same letter are not different at the probability indicated.

* See in material and method the complete area names.

\section{DISCU SSIO N}

The present survey confirms that copepods are common and well distributed in natural water bodies both in urban and suburban areas of Campinas. They were not found in only two downtown artificial pools, probably due to the frequent cleaning that involves complete drainage every two months. In LPARA, also an artificial downtown pool, drainage and cleaning was done 5 months before collections, and at least $E$. serrulatus could be found in abundance.

Physical analysis of the water where copepods were found showed a pH ranging from 6.5 to 8.5 and dissolved $\mathrm{O}_{2}$ from 2.0 to $17.0 \mathrm{ppm}$. Nitrite and nitrate varied from 0.01 to $0.74 \mathrm{ppm}$ and ammonia from 0.06 to $1.28 \mathrm{ppm}$. Correlation to population density was only found to be "appreciable" for both nitrate $(\mathrm{r}=0.46)$ and nitrite $(\mathrm{r}=0.33)$ and "low" for ammonia $(r=0.25)$, according to Rugg's table ${ }^{20}$. Water tem- perature ranging from 15 to $19^{\circ} \mathrm{C}$ during this study could not account for the absence of copepods in CCONV and TCMEN areas. In UNICA/paras copepods have been frequently found during the winter at temperatures around $15^{\circ} \mathrm{C}$.

According to Reid ${ }^{16}$ late instar copepodids are easily mistaken for adults. Rietzler ${ }^{17}$ has pointed out that copepods begin to prey on such insects as first instar copepodids, the predation rate rising as they mature. Thus, it may not be supposed that the low observed efficiencies recorded in the present study are to be directly explained by the presence of some late instar copepodids in samples TAQUA and PEMJS.

Statistical analysis of the predation trials showed the best results for the sample containing only $M$. longisetus var. longisetus (UNICA/paras), with no differences in the trials with the same species cultured under laboratory conditions (ML-01). A lower efficiency was found for two samples: one with both $M$. longisetus var. longisetus plus T. prasinus (PEMJS) and the other with Eucyclops sp plus $M$. albidus var. albidus plus E. solitarius (DPEDR). The present results confirm the good potential of $M$. longisetus var. longisetus and suggest that $M$. albidus var. albidus was the main predator in this last sample (DPEDR), as both species have been shown to be the most effective against Ae. albopictus larvae ${ }^{8}$.

It may be concluded that the copepods found of the genera Eucyclops, Tropocyclops and Metacyclops have poor predatory potential against Ae. albopictus larvae. Samples containing only copepods of the genus Eucyclops showed predation varying from nil to $3.42 \%$. The sample with only $M$. mendocinus showed a percentage not significantly different from that range, and the sample with $T$. 
prasinus (PEMJS) showed a significantly higher efficiency, but probably due to the presence of one individual of M. longisetus var. longisetus. Copepod efficiency as a mosquito predator can be discussed in terms of the adult size of the different species. In the data presented by Reid ${ }^{16}$ a mean length of $0.87 \mathrm{~mm}$ is given for adults of the presently evaluated species in Eucyclops, Metacyclops and Tropocyclops, irrespective of sex. Indeed, copepod species represented by small individuals are quite common in mosquito breeding habitats but they are not such good predators as those represented by larger individuals such as those of the genera Macrocyclops and Mesocyclops (mean length $1.45 \mathrm{~mm})^{9}$. While one individual of the largest copepod species (Macrocyclops or Mesocyclops) can prey on as many as 50 larvae/day ${ }^{10}$, the smallest ones attack mosquito larvae in groups, though not compensating in numbers for the disadvantage of their size (C. E. Rocha, State University of S. Paulo, personal communication).

From these findings $M$. longisetus var. longisetus remains the most promising species among the copepods for use as a biological agent to be introduced in natural breeding places in Campinas. At

\section{REFEREN CES}

1. ABBOTT,W.S. A method of computing the effectiveness of an insecticide. J. Econ. Entomol., 18: 265-7, 1925.

2. BROWN, M.D.; KAY, H.B.; HENDRIKZ, K.J. Evaluation of Australian Mesocyclops (Cyclopoida: Cyclopidae) for mosquito control. J. Med. Entomol., 28: 618-23, 1991.

3. FORATTINI, O. P. Aedes (Stegomyia) albopictus (Skuse) identification in Brazil. Rev. Saúde Pública, 20: 244-5, 1986.

4. GOMES, A.C.; FORATTINI, O.P.; KAKITANI, I.; MARQUES, G.R.A.M.; MARQUES, C.C.A.; MARUCCI, D.; BRITO, M. Microhabitats de Aedes albopictus (Skuse) na região do Vale do Paraíba, Estado de São Paulo, Brasil. Rev. Saúde Pública, 26: 108-18, 1992.

5. KAY, B.H.; CABRAL, C.P.; SLEIGH, A.C.; BROWN, M.D.; RIBEIRO, Z.M.;VASCONCELOS, W.A. Laboratory evaluation of Brazilian Mesocyclops (Copepoda, Cyclopidae) for mosquito control. J. Med. Entomol.,29: 599-602, 1992.

6. MARTEN, G.G. Impact of the copepod Mesocyclops leuckarti pilosa and the green alga Kirchneriella irregularis upon larval Aedes albopictus (Diptera, Culicidae). Bull. Soc.Vector Ecol., 9: 1-5, 1984.

7. MARTEN, G.G.; ASTAIZA, R.; SUÁREZ, M.F.; MONJE, C.; REID, J.W. Natural control of larvalAnopheles albimanus (Diptera, Culicidae) by predator Mesocyclops (Copepoda, Cyclopidae). J. Med. Entomol., 26: 624-7, 1989. the present time, no species so far screened shows such good potential as M. longisetus var. longisetus for use in trap tires.

\section{CONCLUSION}

Copepods, represented in the present survey by eight species of five genera, are easily found in bodies of water from central urban and suburban locations in Campinas, SP, Brazil.

M. longisetus var. longisetus, a copepod already used in biological control projects, was found in only two out of eleven breeding places, occurring along with Tropocyclops prasinus in a 10 ha lake, and alone in a $1 \mathrm{~m}^{3}$ rain water reservoir.

Predation trials against $1^{\text {st }}$ instar Ae. albopictus larvae with samples containing only $M$. longisetus var. longisetus confirmed this latter as a good mosquito controller. The predatory efficiency of a field collected sample of this copepod did not differ from that of a 3-year old laboratory culture.

\section{ACKNO W LED G MENT}

To Dr. C.E. da Rocha (University of S. Paulo) for identifications of copepods.

8. MARTEN, G.G. Evaluation of cyclopoid copepods for Aedes albopictus control in tires. J. Am. Mosq. Control Assoc., 6: 681-8, 1990.

9. MARTEN, G.G. \& BORDES, E.S. Biological control of mosquitoes. Mosquito control Training manual. In: Commercial pesticida aplicatini. 3 ed. New Orleans, Louisiana State University, 1993. Chapter 10.

10. MARTEN, G.G.; BORJAS, M.C.; FERNANDEZ, E.; REID, J.W. Control of larvalAedes aegypti (Diptera:Culicidae) by Cyclopoid Copepods in Peridomestic breeding containers. $J$. Med. Entomol., 31: 36-44, 1994.

11. MARTEN, G.G.; BORDES S. E.; NGUYEN, M. Use of cyclopoid copepods for mosquito control. Hidrobiology, 292-293: 491-6, 1994.

12. NASCI, R.S.; HARE, S.G.F.; VECCHIONE, M. Habitat Associations of Mosquito and Copepod species. J. Am. Mosq. Control Assoc., 3: 593-600, 1987.

13. OSANAI, C. H.; ROSA, A.P.A.T.; TANG, A.T.; AMARAL, R.E.; PASSOS, A.D.C.; TAUIL, P.L. Surto de dengue em Boa Vista, Roraima. (Nota prévia) Rev. Inst. Med. Trop. S. Paulo, 25: 53-4, 1983.

14. PONTES, R.J.S. \& RUFFINO-NETTO, A. Dengue em localidade urbana da região Sudeste do Brasil: aspectos epidemiológicos. Rev. Saúde Pública, 28: 218-27, 1994. 
15. QUIROZ-MARTINEZ, H.; SOLIS-ROJAS, C.; RODRÍGUES-TOVAR, M.L. Field releases of Mesocyclops longisetus (Copepoda, Cyclopidae) for control of Aedes aegypti larvae in 55-gallon metal drums in Monterey, Mexico. Mosquito Vector Control and Biology in Latin America - a third symposium. J. Am. Mosq. Control Assoc., 9: 452, 1993.

16. REID, J.W. Chave de identificação e lista de referências bibliográficas para espécies continentais sulamericanas de vida livre da ordem Cyclopoida. Bol. Zool., 9: 17-143, 1985.

17. RIETZLER, A.C. Alimentação, ciclo de vida e análise de coexistência de espécies de Cyclopoida na Represa de Barra Bonita, São Carlos, 1994. [Tese de Doutorado - Escola de Engenharia de São Carlos da USP].

18. RIVIERE, F. \& THIREL, R. La prédation du copépode Mesocyclops leuckarti pilosa (Crustacea) sur les larves de Aedes (Stegomyia) aegypti et de Ae. (ST.) polynesiensis (Dip.: Culicidae). Essais preliminaires D'utilisation comme agente de lutte biologique. Entomophaga, 26: 427-39, 1981.

19. SANTOS, L.U.; ANDRADE, C. F.S.; CARVALHO, G.A. Biological control of Aedes albopictus (Diptera: Culicidae) larvae in trap tires by Mesocyclops longisetus (Copepoda: Cyclopidae) in two field trials. Mem. Inst. Oswaldo Cruz, 9: 161-2,1996.

20. SOUNIS, E. Bio-Estatística. Rio de Janeiro, Ed. McGraw Hill, 1972.

21. SUAREZ, M.F.; AYALA, D.; NELSON, M.J.; REID, J.W. Hallazgo de Mesocyclops aspericornis (Daday) (Copepoda, Cyclopidae) depredador de larvas de Aedes aegypti en Anapoima-Colombia. Biomédica, 4: 74-6,1984.

22. SUPERINTENDÊNCIA DO CONTROLE DE ENDEMIAS (SUCEN). Municípios infestados por Aedes. São Paulo, 1996.

23. VASCONCELOS, A.W.; SLEIGH, A.C.; KAY, B. H.; CABRAL, C.P.; ARAÚJO, D.B.; RIBEIRO, Z.M.; BRAGA, P.H.; CAVALCANTE,J.S. Community use of copepods to control Aedes aegypti in Brazil. In: Halstead, S. B. \&. Gómez-Dantes, H., ed. Dengue: a worldwide problem, a common strategy, Mexico, The Rockefeller Foundation and Ministry of Health, 1992. p. 139-44. 